\title{
STC1 wt Allele
}

National Cancer Institute

\section{Source}

National Cancer Institute. STC1 wt Allele. NCI Thesaurus. Code C52430.

Human ST C1 wild-type allele is located within 8p21-p11.2 and is approximately $13 \mathrm{~kb}$ in length. This allele, which encodes stanniocalcin 1 protein, plays a role in the mediation of calcium homeostasis. The gene has altered expression in hepatocellular, ovarian, and breast cancers. 